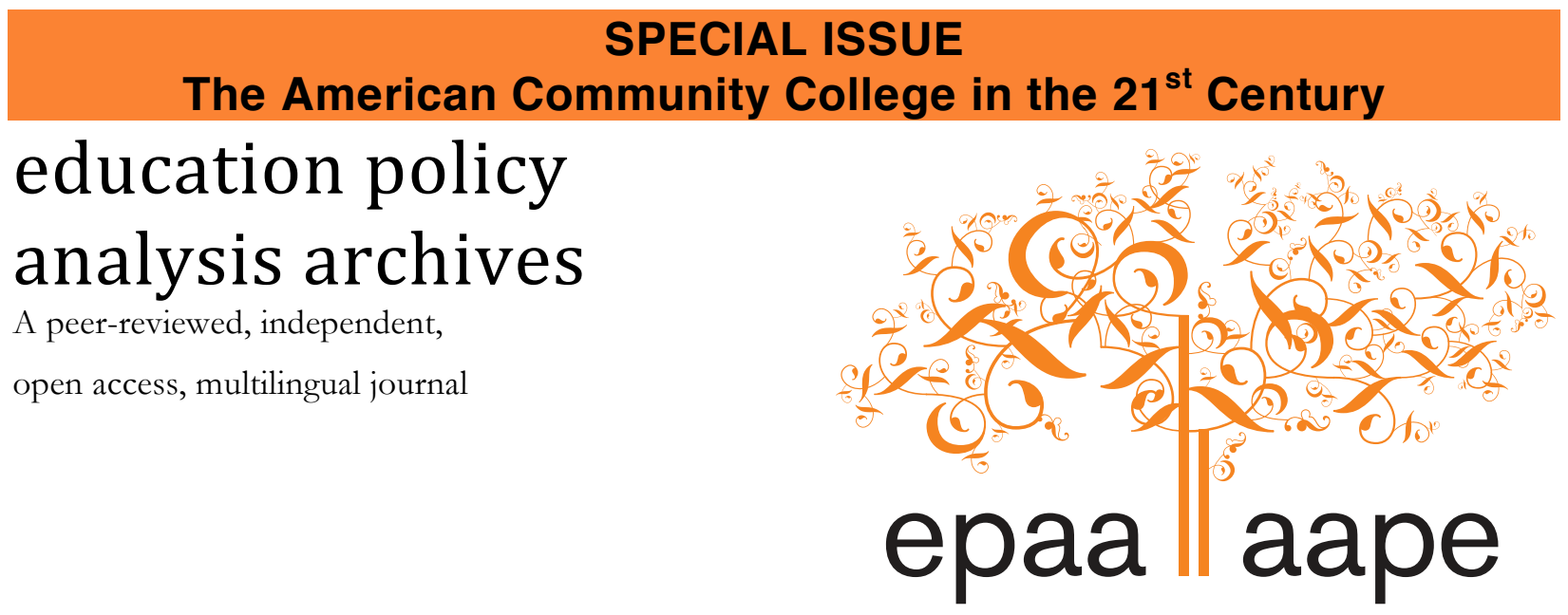

Arizona State University

\title{
K-12 and Postsecondary Alignment: Racial/Ethnic Differences in Freshmen Course-taking and Performance at California's Community Colleges
}

\author{
Michal Kurlaender \\ University of California, Davis \\ United States of America \\ Matthew F. Larsen \\ Tulane University \\ United States of America
}

Citation: Kurlaender, M. \& Larsen, M. (2013). K-12 and postsecondary alignment: Racial/ethnic differences in freshmen course-taking and performance at California's community colleges. Education Policy Analysis Archives, 21(16). This article is part of EPAA/AAPE's Special Issue on Democracy's College: The American Community College in the $21^{\text {st }}$ Century, Guest Edited by Dr. Jeanne M. Powers and Amelia M. Topper. Retrieved [date], from http://epaa.asu.edu/ojs/article/view/1195

\begin{abstract}
In this paper we focus on California high school students' transition to community colleges. Our unique dataset tracks five cohorts of California high school juniors into their freshmen year at in-state community colleges. We evaluate the extent to which high school achievement tests (currently not utilized by community colleges in course placement decisions) are useful for predicting academic success at community college. In addition, given persistent disparities in college attainment by race, we explore whether this fundamental relationship between high school


achievement, college course-taking, and performance differs for students from different racial/ethnic backgrounds.

Keywords: community colleges, college readiness, racial/ethnic differences in collegiate outcomes

Alineamiento K-12 y estudios universitarios: diferencias raciales/étnicas en rendimiento de estudiantes tomando cursos universitarios introductorios en universidades comunitarias de California.

Resumen: En este artículo nos centramos en la transición de estudiantes de escuelas secundarias a universidades comunitarias en California. Nuestra base de datos rastrea cinco cohortes de jóvenes egresados de escuelas secundarias de California en su primer año en universidades comunitarias del estado. Se evalúa el grado en que las pruebas de rendimiento escolar (en la actualidad no se utilizan por universidades comunitarias en las decisiones de asignación de cursos) son útiles para predecir el éxito académico en las universidades comunitarias. Además, teniendo en cuenta la persistencia de disparidades raciales en estudios universitarios, se explora si esta relación fundamental entre logros académicos en la escuela secundaria, asistencia a cursos universitarios y rendimiento es diferente para estudiantes de diferentes orígenes raciales/étnicos.

Palabras clave: universidades comunitarias; preparación para la universidad; diferencias raciales/étnicos en resultados académicos.

Alinhando educação básica e estudos universitários: diferenças raciais / étnicas no desempenho de "calouros" em universidades comunitárias na Califórnia.

Resumo: Neste artigo focalizamos a transição de alunos do ensino médio para universidades comunitárias na Califórnia. Nosso banco de dados rastreia cinco coortes de jovens que concluíram o Ensino Médio na Califórnia em seu primeiro ano em universidades comunitárias do estado. Ele avalia em que medida os testes de desempenho escolar (atualmente não utilizados por universidades comunitárias como critério de ingresso) são úteis na previsão de sucesso escolar em universidades comunitárias. Além disso, dada a persistência de disparidades raciais no Ensino Superior, exploramos se esta relação fundamental entre desempenho acadêmico no ensino médio, cursos universitários e desempenho é diferente para alunos de diferentes raças / etnias.

Palavras-chave: universidades comunitárias, preparação da faculdade, raciais / étnicas resultados acadêmicos.

\section{Introduction}

Many college students arrive as freshmen unprepared to do college level work.

Rates of remedial or developmental course enrollment vary substantially across colleges and universities, but reports from the Community College Research Center indicate that it is "reasonable to conclude that two-thirds or more of community college students enter college with academic skills weak enough in at least one major subject area to threaten their ability to succeed in collegelevel courses" (Bailey, 2009, p.13). One reason for the low rates of college readiness may be students' limited information about what they need to do to succeed in college (Person, Rosenbaum, \& Deil-Amen, 2006; Rosenbaum, 2001; Venezia, Kirst, \& Antonio, 2003). The fact that most public secondary and postsecondary systems of education are badly misaligned (Kirst \& Venezia, 2004) may contribute to this information gap. Students may only come to an understanding of the academic demands of college after they enter college.

The recent drive to adopt Common Core State Standards (adopted by 45 states at the time of this writing) has led to a growing interest in the possibility that seemingly disparate educational 
systems of secondary and postsecondary schooling might be better connected, particularly through the assessment process. Typically, however, the tests on which secondary and postsecondary systems rely have remained separate in their purposes and uses (Kurlaender, Grodsky, Agronow, \& Horn, 2011). High school end-of-course exams define what is important to learn and teach at the secondary school level, and can (arguably) act as motivators for students on the path for further schooling. In contrast, college entrance exams serve as a way of measuring "future promise independent of past opportunity" (Crouse \& Trusheim, 1988, p. 24). In an increasingly K-16 policy environment, it is important to consider whether and how tests used to monitor the progress of students through secondary education might provide useful information about college readiness and success.

In this paper we focus on California high school students' transition to in-state community colleges. Our unique dataset, which tracks California students from the $\mathrm{K}-12$ to the postsecondary system, allows us to evaluate the extent to which prior high school achievement tests (currently not utilized by community colleges in course placement decisions) are useful for predicting academic success at community college. In addition, given persistent disparities in college attainment by race, we explore whether this fundamental relationship between high school achievement and college course-taking and performance differs for students from different racial/ethnic backgrounds.

Our paper contributes to the existing literature on the determinants of postsecondary achievement in several important ways. First, we draw on one of the richest administrative data sources from an important state; California serves students from a tremendous range of ethnic and socioeconomic origins, and offers great individual and institutional diversity. The California Community College system consists of 112 campuses and is one of the largest public higher education systems in the country, enrolling over 2.6 million students annually (California Community College Chancellor's Office, 2012). These students come from urban, suburban, and rural areas and attended public high schools that are both among the best and among the worst in the nation. While California may not be a typical state, it reflects the student populations of other states in the U.S. and the community colleges that educate them. Moreover, our detailed longitudinal data on all California high school juniors who enter one of the state's public community colleges provides an unprecedented opportunity to explore alignment between the state's $\mathrm{K}-12$ mandated assessments and postsecondary outcomes. It also allows us to explore how students who perform similarly on the statewide accountability tests fare as freshmen at different community college campuses, and as a result of attending different California high schools. Finally, we extend the prior literature on college readiness by exploring how high school attendance and performance may affect college success differently for students from different racial/ethnic backgrounds.

\section{Background and Context}

The accumulation of academic skills and preparation in high school is one of the key determinants of college outcomes (Adelman, 1999, 2006; Long, Iatarola, \& Conger, 2008). Yet, some students arrive at college having attended elementary and secondary schools of low quality or with weak academic rigor. Students who attend poor-quality schools may not receive the necessary grounding in core subjects such as English and math to engage successfully in college-level work (Achieve, 2004). Of course, students may also come to college with deficiencies in core subjects even if they attend adequate or superior schools due to lack of attention to their studies, existing learning disabilities, or perhaps because they are English language-learners.

Students are also often wildly misinformed about the skills necessary to succeed in college (Person, Rosenbaum, \& Deil-Amen, 2006; Rosenbaum, 2001; Venezia, Kirst, \& Antonio, 2003). A 
majority of high school students-regardless of their academic performance-report that they will attend college (Bozick \& Lauff, 2007). In fact, academic performance accounts for little of the variance in students' expected levels of educational attainment, suggesting that students' actual grades in high school often do not correlate with their educational expectations. Reynolds, Stewart, MacDonald, \& Sischo (2006) found that between 1976 and 2000 the percentage of high school seniors indicating that they probably or definitely would complete at least a baccalaureate degree increased from 50 percent to 78 percent. At the same time, Rosenbaum and others have documented that high school seniors have little understanding of what it takes to succeed in higher education (Conley, 2005; Deil-Amen \& Rosenbaum, 2002; Rosenbaum, 2001; Venezia, Kirst, and Antonio, 2004).

One indication of misalignment between secondary and postsecondary systems is evidenced by the high rates of college remediation. ${ }^{1}$ Rates of remedial or developmental course enrollment vary substantially across colleges and universities; estimates from the most recent national longitudinal study of high school graduates suggests that nearly a quarter of all students entering four-year institutions require some remediation in reading, writing, and/or math (Snyder, Tan, \& Hoffman, 2004). Rates are significantly higher at two-year open-access institutions, where many students begin their postsecondary study, and are generally higher for some sub-groups, particularly African American, Hispanic students, and for English learners (Perrin, 2006; Appendix Table A1).

Lack of academic preparation for college has important consequences for both individuals and society. College remediation is expensive-to students, their families, colleges, and taxpayers. There are large direct costs of providing developmental instruction in higher education for skills that should have been mastered in high school (Phipps, 1998). In addition to the direct costs for developmental instruction, there are also many hidden costs - foregone earnings for students who need a longer course of study to obtain their degrees, and potentially social costs for remediated students, such as frustration or low self-esteem (Deil-Amen \& Rosenbaum, 2002).

Students who arrive at college in need of developmental coursework are less likely to succeed - in their performance, persistence, and degree completion-in college. For example, less than one-quarter of community college students in the National Educational Longitudinal Study (NELS:88) sample who enrolled in developmental education complete a degree or certificate within eight years of enrollment in college. In comparison, almost 40 percent of community college students in the NELS sample who did not enroll in any developmental education course complete a degree or certificate in the same time period (U.S. Department of Education, National Center for Education Statistics, 2003). But it is not remedial programs or developmental coursework that causes the weaker outcomes we observe. Such programs are intended to overcome the deficiencies that many students face, and it is therefore quite likely that academically unprepared students would fare even worse if these programs did not exist. The research base on the effectiveness of remedial education programs reveals at best a mixed bag of results, suggesting that students enrolled in developmental coursework do no better (and at times slightly worse) when compared to similar students (Attewell, Lavin, Domina, \& Levey, 2006; Bettinger \& Long 2009; Boatman \& Long 2010; Calcagno \& Long, 2008; Lesik, 2007; Martorell \& McFarlin, 2007; Scott-Clayton \& Rodriguez, 2012).

\footnotetext{
${ }^{1}$ Remedial education in postsecondary schooling aims to improve the basic literacy skills (primarily in math, reading, and writing) of students who arrive at college unprepared to do college-level work. Some scholars and educators prefer to use the term "developmental" education, rather than "remedial." This avoids creating a deficit framework of what students do not know, instead favoring a developmental approach that suggests a continuum of learning. In this paper we use the terms remedial and developmental education interchangeably.
} 
Collegiate remediation is costly, but the price of not assisting more young people in their pursuit of degree completion may be even higher. The earnings gap between college educated and non-college educated adults continues to grow (College Board, 2010), as do the labor market demands for more highly skilled workers (Goldin, and Katz, 2008). As such, there is a great need to understand the complex transition students face from secondary to postsecondary study, and the conditions necessary to ensure more students persist in college.

It is becoming increasingly clear that the transition between high school and college is not a seamless one, and that our $\mathrm{K}-12$ system is grossly misaligned with the expectations of colleges and universities (Hoffman, Vargas, Venezia, \& Miller, 2007). Some fault the "wasted" senior year, during which many students experience less rather than more rigor in their academic program (Kirst, 2000; National Commission on the High School Senior Year, 2001). Others suggest that state performance standards are detached from those that might assist students in higher education (Venezia, Callan, Finney, Kirst, \& Usdan, 2005). Finally, still others point out that the current accountability regime has focused attention in $\mathrm{K}-12$ on meeting basic competency, for example in high school exit exams, perhaps at the expense of meeting the expectations of postsecondary schooling (Achieve, 2004; Strong American Schools, 2008). Recent efforts of the Common Core State Standards (further discussed below) suggest that this may be changing.

In this paper we investigate what California's high school assessments, for accountability under NCLB, can inform us about the course-taking and performance outcomes of community college students. Specifically, we explore the following research questions: (1) To what extent do standardized tests in high school predict course taking and performance among traditional age first time freshmen at California's community colleges? (2) Does this differ by students' race/ethnicity? And, (3) to what extent can differences be attributed to the high schools and community college campuses attended?

\section{Data and Analytic Strategy}

To conduct our analysis we matched community college data on four cohorts of first-time freshmen (made available by the California Community College Chancellor's Office) to standardized test score data for California high school juniors (made available from the California Department of Education). We arrived at our analytic sample in the following steps. First, we began with the Chancellor's Office derived first time freshmen cohorts, including students' demographic characteristics. Second, we limited the sample to students between the ages of 17 and 19 who have completed high school, and who are enrolled in two or more credit and non-occupational courses. ${ }^{2}$ Finally, we matched each of these cohorts to our California Department of Education (CDE) dataset of the census of California's high school juniors based on last name, first name, date of birth, high school attended, and cohort (obtaining roughly a 73 percent match rate). We did this for freshmen cohorts beginning in fall 2005 to fall 2009. We observed student course-taking behavior during their first two terms on the measures described below.

\footnotetext{
2 We start with all students who are labeled as a first time (and non-special admit) student in each fall term (2005-2009). Then we limit the sample to those students who are between the ages of 17 and 19. Next, we attach student course information and limit the sample to students who took 2 or more credit bearing, nonoccupational courses in both their first fall term and the following spring term. The sample is limited further to students who were correctly matched to their high school record.
} 


\section{Measures}

We explored the potential influence of high school achievement on four first-year outcomes at community college: (1) fraction of courses identified as transferable to the California's dominant BA-granting institution, the California State University (CSU) system ${ }^{3}$; (2) fraction of courses identified as "basic skills"-California Community Colleges" primary classification for developmental courses; (3) freshmen academic performance as measured by student Grade Point Average (GPA) in CSU transferable courses; and (4) GPA in basic skills courses. We examine these outcomes in English and math basic skills courses respectively.

It is important to note that students end up in particular courses, particularly basic skills courses, in a variety of ways that are both dependent on the individual and the campus enrollment policies. Referrals to basic skills coursework vary widely for several reasons: the 112 California community college campuses have different placement tests and cutoff scores for determining course levels; campuses often have constraints in offering enough sections of the necessary basic skills courses; and, there are different levels of enforcement that students enroll in such courses. Although we cannot model these distinctions, we can control for between campus differences in these dimensions (further described below). Given that all colleges have different assessments, thresholds, offerings, and enforcement around developmental course-taking, we find that these measure offer a more nuanced way to think about what developmental course-taking looks across the system, i.e. who is actually enrolled in what types of courses.

All students in $11^{\text {th }}$ grade take the same English California Standardized Test (CST) and, based on test score results, students are assigned a proficiency level. The proficiency categories are: Far Below Basic (12 percent of all students in CA in 2011), Below Basic (14 percent), Basic (28 percent), Proficient (24 percent), and Advanced (21 percent). ${ }^{4}$ Schools benefit from having more students in the Proficient or Advanced categories, as those two categories contribute to their federal Adequate Yearly Progress (AYP) measures under the No Child Left Behind Act (NCLB). In math, however, students take a different test depending on their level of coursework; thus, in math, in addition to the test score we also included test level taken. To answer the second research question we also included a set of dummy variables to test for differences by student race/ethnicity, and additional control variables, including gender and parental education levels. Finally, we included a dummy variable for cohort affiliation to capture any other unobserved temporal dimensions in both high school test performance and in community college outcomes. ${ }^{5}$

Tables 1 and 2 include summary statistics by the two sub-samples: English and Math, and Table 2 by student race/ethnicity. As detailed above, our analytic sample included five cohorts of all first-time freshmen at community colleges who we were able to successfully match from their junior year attendance at a California public high school. Our sample, represented the overall demographics of California's high school graduating classes, about 38 percent white, 6 percent

\footnotetext{
${ }^{3}$ California has a well articulated system of higher education, where the University of California's 10 campuses are selective to highly selective research universities admitting the state's top 12.5 percent of high school graduates, the California State University's 23 campuses range from moderately selective to nonselective, admitting the state's top 33 percent of the high school graduating class, and finally, the 112 campuses of the California Community Colleges, entirely open access institutions. We also explore University of California (UC) transferable course, however, given that courses deemed CSU transferable are also, by in large, UC transferable, our results are virtually the same.

${ }^{4}$ Source: California Department of Education, http://star.cde.ca.gov/.

${ }^{5}$ We also do additional analysis that control for campus enrollment to capture any potential unobserved differences in these outcomes by community college campus; results do not differ substantially when we include fixed effects at the campus level (these may be obtained from the authors upon request).
} 
African American, 41 percent Latino, 14 percent Asian, and 2 percent other race/ethnicities. Females make up 53 percent of the sample, and 65 percent of the sample had at least one parent attend some college.

Students in our sample had an average English CST score of 333 (slightly below the mean scale score of 341 for all $11^{\text {th }}$ grade test takers statewide), with notable gaps by student race/ethnicity. Average high school test scores among entering freshmen at California's community colleges are lower for African American and Latino students relative to white and Asian students. About 70 percent of courses first time freshmen at California's community colleges enroll in are CSU (or UC) transferable. About 32 percent of all students enroll in some English basic skills course as first-time freshmen, and about 6 percent enroll in at least one math basic skills course. However, among all courses students enroll in as first-time freshmen, only 7 percent are "basic skills in English" and about 4 percent of courses are designated as "basic skills in math." Since in subsequent models we operationalize developmental course-taking as a percentage of all courses that are developmental or basic skills it is important to clarify that although these rates of the fraction of courses that are basic skills may seem low, they are exactly as described-percentages of all courses taken. Thus, for example, even if every student took exactly 1 remedial math class their first semester-say out of 10 total courses their first year-this would be 10 percent. Finally, students' average first year cumulative GPA in four-year transferable courses is about 2.25. However, cumulative GPA is on average lower in courses that are deemed "basic" or "remedial," 1.71 in English basic skills courses and 1.94 in math basic skills courses.

\footnotetext{
6 The patterns are quite similar when looking at the percent of units rather than classes, though slightly higher proportions of units are devoted to remedial courses, than are proportion of courses, suggesting that the average remedial course may be worth more units than the average non-remedial course. These additional summary statistics are available from the authors upon request.
} 
Table 1

Summary Statistics

CST English Test Sample

English CST Score

Fraction of Courses CSU Transferable

Fraction of Courses Basic Skills - English

CSU Transferable GPA

Basic Skills - English GPA

Female

Parent College

White

African American

Hispanic

Asian

Other

Math CST Score

Fraction of Courses CSU Transferable

Fraction of Courses Basic Skills - Math

CSU Transferable GPA

Basic Skills - Math GPA

Female

Parent College

White

African American

Hispanic

Asian

Other

$11^{\text {th }}$ grade CST Test: Algebra 1

$11^{\text {th }}$ grade CST Test: Algebra 2

$11^{\text {th }}$ grade CST Test: Geometry

$11^{\text {th }}$ grade CST Test: Summative Math

\begin{tabular}{ccccc}
\hline $\begin{array}{c}\text { Number of } \\
\text { Students }\end{array}$ & Mean & $\begin{array}{c}\text { Standard } \\
\text { Deviation }\end{array}$ & Min & Max \\
\hline 356,278 & 333.24 & 55.53 & 150 & 600 \\
356,278 & 0.69 & 0.23 & 0 & 1 \\
356,278 & 0.07 & 0.12 & 0 & 1 \\
348,317 & 2.25 & 1.04 & 0 & 4 \\
115,105 & 1.71 & 1.26 & 0 & 4 \\
353,323 & 0.53 & 0.5 & 0 & 1 \\
282,919 & 0.65 & 0.48 & 0 & 1 \\
319,362 & 0.38 & 0.48 & 0 & 1 \\
319,362 & 0.06 & 0.24 & 0 & 1 \\
319,362 & 0.41 & 0.49 & 0 & 1 \\
319,362 & 0.14 & 0.34 & 0 & 1 \\
319,362 & 0.02 & 0.13 & 0 & 1
\end{tabular}

\section{CST Math Test Sample}

\begin{tabular}{ccccc}
\hline $\begin{array}{c}\text { Number of } \\
\text { Students }\end{array}$ & Mean & $\begin{array}{c}\text { Standard } \\
\text { Deviation }\end{array}$ & Min & Max \\
\hline 302,200 & 292.47 & 49.02 & 150 & 600 \\
302,200 & 0.7 & 0.23 & 0 & 1 \\
302,200 & 0.04 & 0.08 & 0 & 0.83 \\
296,015 & 2.29 & 1.03 & 0 & 4 \\
53,700 & 1.94 & 1.24 & 0 & 4 \\
299,729 & 0.52 & 0.5 & 0 & 1 \\
240,226 & 0.65 & 0.48 & 0 & 1 \\
271,088 & 0.37 & 0.48 & 0 & 1 \\
271,088 & 0.06 & 0.24 & 0 & 1 \\
271,088 & 0.41 & 0.49 & 0 & 1 \\
271,088 & 0.14 & 0.35 & 0 & 1 \\
271,088 & 0.02 & 0.13 & 0 & 1 \\
302,200 & 0.13 & 0.34 & 0 & 1 \\
302,200 & 0.4 & 0.49 & 0 & 1 \\
302,200 & 0.28 & 0.45 & 0 & 1 \\
302,200 & 0.2 & 0.4 & 0 & 1
\end{tabular}


Table 2

Summary Statistics by Race/Ethnicity

English CST Score - White

English CST Score - African American

English CST Score - Hispanic

English CST Score - Asian

English CST Score - Other

Math CST Score - White

Math CST Score - African American

Math CST Score - Hispanic

Math CST Score - Asian

Math CST Score - Other

\begin{tabular}{ccccc}
\multicolumn{5}{c}{ CST Math Test Sample } \\
\hline $\begin{array}{c}\text { Number of } \\
\text { Students }\end{array}$ & Mean & $\begin{array}{c}\text { Standard } \\
\text { Deviation }\end{array}$ & Min & Max \\
\hline 120,097 & 347.87 & 56.5 & 150 & 600 \\
19,877 & 308.54 & 52.63 & 163 & 600 \\
130,494 & 321.49 & 50.96 & 150 & 600 \\
43,516 & 334.63 & 53.84 & 150 & 600 \\
5,378 & 330.62 & 55.03 & 153 & 571 \\
99,745 & 301.38 & 49.82 & 150 & 600 \\
16,251 & 270.95 & 40.96 & 150 & 559 \\
111,427 & 282.71 & 44.03 & 150 & 600 \\
39,229 & 305.13 & 54.36 & 150 & 600 \\
4,436 & 291.14 & 46.03 & 150 & 600
\end{tabular}

\section{Analysis Plan}

To assess the extent to which high school standardized tests may be associated with community college success we fit a series of regression models predicting a host of placement and performance outcomes, as a function of CST performance in math and English respectively, controlling for students' demographic characteristics, high school of attendance and cohort affiliation:

$$
\mathrm{Y}_{\mathrm{is}}=\beta \mathrm{X}_{\mathrm{is}}+\alpha_{1} \mathrm{CST}_{\mathrm{is}}+\varepsilon_{\mathrm{is}}
$$

Where $Y_{\text {is }}$ represents an individual student $i$ in subject $s$ 's outcomes (specifically: fraction of transferable courses; fraction of basic skills courses, and grade point average), in math and English respectively, as a function of their performance in high school, and a vector of control variables X: gender, parental education, race/ethnicity and cohort. To model the correct functional form of CST performance, we include higher order polynomial terms to account for nonlinearities. We also test additional models that include high school and community college fixed effects to account for between high school variation in academic preparation and between campus differences in course placement and grades.

To address the second research question, we test whether these relationships may differ by race/ethnicity. We add to equation (1) a series of interactions between student test score and race/ethnicity dummy variables. To highlight the results from our models, we plot predicted values of each of our outcomes for each racial/ethnic group.

\section{Findings}

Table 3 details the results from a set of fitted regression models predicting four respective outcomes of first time freshmen course-taking and performance at community colleges as a function of their $11^{\text {th }}$ grade English CST scores. The top panel looks at fraction of courses that are transfer level (Models 1-3) and the fraction of courses that are identified as English basic skills (Models 4-6). 
The bottom panel looks at performance, measured as GPA in transferable courses (Models 1-3) and GPA in English basic skills courses (Models 4-6). Models are nested, first estimating unadjusted differences in these outcomes on the basis of only $11^{\text {th }}$ grade tests and cohort fixed effects. We next add demographic controls (race/ethnicity, gender, and parent college attendance), and finally campus fixed effects to account for the differences between campuses in course-taking and performance measures.

Table 3

Results from OLS Regressions - English

\begin{tabular}{|c|c|c|c|c|c|c|}
\hline \multicolumn{7}{|c|}{ Fraction of College Classes Taken that are: } \\
\hline & \multicolumn{3}{|c|}{ CSU Transfer Level Courses } & \multicolumn{3}{|c|}{ English Basic Skills Courses } \\
\hline & (1) & (2) & (3) & (4) & (5) & (6) \\
\hline CST English Score & $\begin{array}{c}0.0003^{* * *} \\
(0.0001)\end{array}$ & $\begin{array}{c}0.0007^{* * *} \\
(0.0001)\end{array}$ & $\begin{array}{c}0.0008^{* * *} \\
(0.0001)\end{array}$ & $\begin{array}{c}-0.0012 * * * \\
(0.0001)\end{array}$ & $\begin{array}{c}-0.0014 * * * \\
(0.0001)\end{array}$ & $\begin{array}{c}-0.0014 * * * \\
(0.0001)\end{array}$ \\
\hline CST English Score Squared & $\begin{array}{c}2.2 \mathrm{E}-6^{* * *} \\
(1.5 \mathrm{E}-7)\end{array}$ & $\begin{array}{c}1.3 \mathrm{E}-6 * * * \\
(1.5 \mathrm{E}-7)\end{array}$ & $\begin{array}{c}1.2 \mathrm{E}-6 * * * \\
(1.4 \mathrm{E}-7)\end{array}$ & $\begin{array}{c}6.3 \mathrm{E}-7 * * * \\
(9.7 \mathrm{E}-8)\end{array}$ & $\begin{array}{c}1.0 \mathrm{E}-6^{* * *} \\
(1.0 \mathrm{E}-7)\end{array}$ & $\begin{array}{c}1.0 \mathrm{E}-6 * * * \\
(9.3 \mathrm{E}-8)\end{array}$ \\
\hline Number of Observations & 356,278 & 252,383 & 252,383 & 356,278 & 252,383 & 252,383 \\
\hline R-Squared & 0.19 & 0.23 & 0.31 & 0.13 & 0.15 & 0.29 \\
\hline \multicolumn{7}{|c|}{ GPA in College Classes Taken that are: } \\
\hline & \multicolumn{3}{|c|}{ CSU Transfer Level Courses } & \multicolumn{3}{|c|}{ English Basic Skills Courses } \\
\hline & (1) & (2) & (3) & (4) & (5) & (6) \\
\hline CST English Score & $\begin{array}{l}-0.0004 \\
(0.0003)\end{array}$ & $\begin{array}{l}-0.0006 \\
(0.0004)\end{array}$ & $\begin{array}{l}-0.0002 \\
(0.0004)\end{array}$ & $\begin{array}{c}0.0023^{* *} \\
(0.0010)\end{array}$ & $\begin{array}{c}0.0030^{* * *} \\
(0.0012)\end{array}$ & $\begin{array}{c}0.0039^{* * *} \\
(0.0010)\end{array}$ \\
\hline CST English Score Squared & $\begin{array}{c}8.1 \mathrm{E}-6 * * * \\
(4.8 \mathrm{E}-7)\end{array}$ & $\begin{array}{c}\text { 7.7E-6*** } \\
(5.3 \mathrm{E}-7)\end{array}$ & $\begin{array}{c}7.2 \mathrm{E}-6^{* * *} \\
(5.2 \mathrm{E}-7)\end{array}$ & $\begin{array}{c}4.9 \mathrm{E}-6^{* * *} \\
(1.7 \mathrm{E}-6)\end{array}$ & $\begin{array}{l}3.5 \mathrm{E}-6 * \\
(1.9 \mathrm{E}-6)\end{array}$ & $\begin{array}{c}7.4 \mathrm{E}-7 \\
(1.5 \mathrm{E}-6)\end{array}$ \\
\hline Number of Observations & 348,317 & 246,794 & 246,794 & 115,105 & 81,305 & 81,305 \\
\hline R-Squared & 0.07 & 0.09 & 0.10 & 0.04 & 0.04 & 0.25 \\
\hline Cohort Fixed Effects & $\mathrm{X}$ & $\mathrm{X}$ & $\mathrm{X}$ & $\mathrm{X}$ & $\mathrm{X}$ & $\mathrm{X}$ \\
\hline Demographic Controls & & $\mathrm{X}$ & $\mathrm{X}$ & & $\mathrm{X}$ & $\mathrm{X}$ \\
\hline College Fixed Effects & & & $\mathrm{X}$ & & & $\mathrm{X}$ \\
\hline
\end{tabular}

*** 1\% Significance Level, $* *$ 5\% Significance Level, * 10\% Significance Level

Notes: Demographic controls include indicator variables for race, gender, and parent college attendance. Cohorts are from the 20052006 school year to the 2009-2010 school year. Standard Errors are clustered at the high school level. GPA is the average Grade Point average in courses taken for a grade. Basic Skills definition is as defined by the California Community College Chancellor's office.

Source: Data are from the California Community College Chancellor's Office

Results from models on course-taking reveal that performance on the $11^{\text {th }}$ grade state standardized tests does have a statistically significant association with course-taking and academic performance, and that this relationship is non-linear. High school students' performance on standardized tests explain about 19 percent of the variation in fraction of courses that are transfer level, and about 13 percent of the variation in fraction of courses that are defined as basic skills. The association persists (though coefficients on CST are smaller) when we account for a variety of demographic characteristics. Finally, when accounting for the between community campus differences in both student backgrounds, and more likely, in course-taking patterns, the effect of high school standardized tests remains statistically significant, and together explain about 30 percent of the variability in course-taking among first time freshmen at California's community colleges.

Turning to the bottom panel of Table 3 predicting performance, we see that although high school performance is associated with cumulative college GPA, it explains much less of the variability in the GPA outcomes compared with course-taking measures. Given the great diversity 
among community college students in academic preparation and in degree intentions, perhaps it is no surprise that their earlier high school performance would not necessarily predict college performance. In fact, together CST scores in English, student background characteristics, cohort fixed effects, and campus fixed effects explain only about 10 percent of the variability in GPA in CSU transfer level courses.

Table 4 details results from a parallel analysis for high school math performance, which reveals a similar statistically significant association between high school performance on the state's standardized tests in math, and course-taking and performance, respectively. Again, we note that the strength of the relationship is weaker for performance relative to types of course-taking. Interestingly, in both math and English, adding covariates - individual characteristics and campus and high school fixed effects—substantially increases the overall R-square.

Table 4

Results from OLS Regressions - Math

\begin{tabular}{|c|c|c|c|c|c|c|}
\hline \multicolumn{7}{|c|}{ Fraction of College Classes Taken that are: } \\
\hline & \multicolumn{3}{|c|}{ CSU Transfer Level Courses } & \multicolumn{3}{|c|}{ Math Basic Skills Courses } \\
\hline & (1) & $(2)$ & (3) & (4) & $(5)$ & $(6)$ \\
\hline CST Math Score & $\begin{array}{c}0.0024^{* * * *} \\
(0.0001)\end{array}$ & $\begin{array}{c}0.0020^{* * *} \\
(0.0001)\end{array}$ & $\begin{array}{c}0.0019 * * * \\
(0.0001)\end{array}$ & $\begin{array}{c}-0.0013 * * * \\
(0.0000)\end{array}$ & $\begin{array}{c}-0.0012^{* * *} \\
(0.0000)\end{array}$ & $\begin{array}{c}-0.0012 * * * \\
(0.0000)\end{array}$ \\
\hline CST Math Score Squared & $\begin{array}{c}-2.0 \mathrm{E}-6 * * * \\
-(1.6 \mathrm{E}-7)\end{array}$ & $\begin{array}{c}-1.6 \mathrm{E}-6 * * * \\
-(1.5 \mathrm{E}-7)\end{array}$ & $\begin{array}{c}-1.5 \mathrm{E}-6 * * * \\
-(1.2 \mathrm{E}-7)\end{array}$ & $\begin{array}{c}1.5 \mathrm{E}-6^{* * * *} \\
-(6.3 \mathrm{E}-8)\end{array}$ & $\begin{array}{l}1.5 \mathrm{E}-6 * * * \\
-(6.1 \mathrm{E}-8)\end{array}$ & $\begin{array}{l}1.4 \mathrm{E}-6 * * * \\
-(5.2 \mathrm{E}-8)\end{array}$ \\
\hline Number of Observations & 303,567 & 215,369 & 215,369 & 303,567 & 215,369 & 215,369 \\
\hline R-Squared & 0.17 & 0.22 & 0.31 & 0.13 & 0.14 & 0.25 \\
\hline \multicolumn{7}{|c|}{ GPA in College Classes Taken that are: } \\
\hline & \multicolumn{3}{|c|}{ CSU Transfer Level Courses } & \multicolumn{3}{|c|}{ Math Basic Skills Courses } \\
\hline & (1) & $(2)$ & $(3)$ & (4) & $(5)$ & $(6)$ \\
\hline CST Math Score & $\begin{array}{c}0.0058^{* * *} \\
-(0.0003)\end{array}$ & $\begin{array}{c}0.0042^{* * *} \\
-(0.0004)\end{array}$ & $\begin{array}{c}0.0045^{* * *} \\
-(0.0004)\end{array}$ & $\begin{array}{c}0.0120 * * * \\
-(0.0016)\end{array}$ & $\begin{array}{l}0.0093^{* * *} \\
-(0.0020)\end{array}$ & $\begin{array}{c}0.0094^{* * *} \\
-(0.0019)\end{array}$ \\
\hline CST Math Score Squared & $\begin{array}{c}-3.7 \mathrm{E}-6 * * * \\
-(5.4 \mathrm{E}-7)\end{array}$ & $\begin{array}{l}-1.5 \mathrm{E}-6 * * \\
-(6.0 \mathrm{E}-7)\end{array}$ & $\begin{array}{c}-2.0 \mathrm{E}-6 * * * \\
-(5.8 \mathrm{E}-7)\end{array}$ & $\begin{array}{c}-8.5 \mathrm{E}-6 * * * \\
-(2.9 \mathrm{E}-6)\end{array}$ & $\begin{array}{l}-4.1 \mathrm{E}-6 \\
-(3.5 \mathrm{E}-6)\end{array}$ & $\begin{array}{l}-3.6 \mathrm{E}-6 \\
-(3.4 \mathrm{E}-6)\end{array}$ \\
\hline Number of Observations & 297,327 & 210,980 & 210,980 & 53,949 & 37,758 & 37,758 \\
\hline R-Squared & 0.09 & 0.11 & 0.12 & 0.09 & 0.10 & 0.14 \\
\hline Cohort Fixed Effects & $\mathrm{X}$ & $\mathrm{X}$ & $\mathrm{X}$ & $\mathrm{X}$ & $\mathrm{X}$ & $\mathrm{X}$ \\
\hline Math Test Fixed Effects & $\mathrm{X}$ & $\mathrm{X}$ & $\mathrm{X}$ & $\mathrm{X}$ & $\mathrm{X}$ & $\mathrm{X}$ \\
\hline Demographic Controls & & $\mathrm{X}$ & $\mathrm{X}$ & & $\mathrm{X}$ & $\mathrm{X}$ \\
\hline College Fixed Effects & & & $\mathrm{X}$ & & & $\mathrm{X}$ \\
\hline
\end{tabular}

*** 1\% Significance Level, ** 5\% Significance Level, * 10\% Significance Level

Notes: Demographic controls include indicator variables for race, gender, and parent college attendance. Cohorts are from the $2005-2006$ school year to the 2009-2010 school year. Standard Errors are clustered at the high school level. GPA is the average Grade Point average in courses taken for a grade. Basic Skills definition is as defined by the California Community College Chancellor's office. Only those students who took the Algebra 1, Algebra2, Geometry, or Summative Math test are included in the analysis.

Source: Data are from the California Community College Chancellor's Office

Given the nonlinear nature of the relationship between high school achievement and these course-taking and performance outcomes, it is difficult to directly interpret the slope coefficients. Computing fitted values, we note the difference in the fraction of courses a freshmen takes that are CSU transferable between those in the $25^{\text {th }}$ percentile of CST and the $75^{\text {th }}$ percentile of CST is about 11.3 percentage points in English and 7.2 percentage points in math. The difference in the fraction of basic skills courses between those in the $25^{\text {th }}$ percentile in CST versus those in the $75^{\text {th }}$ percentile is -4.9 percentage points in English and -1.7 percentage points in math. To more fully illustrate 
these differences, we plot the fitted values in Figures 1-6, once we include race/ethnicity into the model.

\section{Differences by Race/Ethnicity}

We next ask whether the relationships we find differ by student race/ethnicity. We find statistically significant differences by race/ethnicity in the association between high school achievement and these community college outcomes, save for the GPA in basic skills courses (full results from these nested models are in Table A2 and A3 in the Appendix). Figures 1 through 4 display results from fitted models where we include a set of interactions between high school CST score and race/ethnicity dummy variables to predict freshmen course-taking. The Y-axis is the fraction of courses that first year students take that are deemed four-year transferable (in percentage terms) and the X-axis indicates these fitted values at the $25^{\text {th }}$ percentile of CST, for each racial/ethnic sub-group respectively, (holding constant all other covariates at the sample mean).

Figures 1 and 2 illustrate that white and Asian students consistently enroll in a higher fraction of CSU transferable courses than their Latino and African American counterparts, holding constant academic achievement in high school in English and math respectively. Moreover, in regards to our research question we note that the pattern of predicted differences in the fraction of courses that are transferable based on prior achievement is different by race/ethnicity. In other words the racial/ethnic gap in course-taking is not consistent by prior achievement. Specifically, we note from Figure 1 the predicted difference in the fraction of courses that are transferable between white and Latino students in the $25^{\text {th }}$ percentile of CST is 13 percentage points, in the $50^{\text {th }}$ percentile it is 12 percentage points, and in the $75^{\text {th }} 11$ percentage points. Between whites and African Americans the difference in the fraction of courses that are transferable actually goes up from 12 percentage points in the $25^{\text {th }}$ percentile of CST to 13 percentage points in the $75^{\text {th }}$ percentile of CST. Although the pattern is similar in math (Figure 2), the racial/ethnic differences are more disturbing, in that we see much larger gaps in four-year transferable course-taking between racial/ethnic groups at higher levels of achievement; this is particularly notable in the white-African American comparison, which indicates a 6.3 percentage point gap in transferable course-taking at the $25^{\text {th }}$ percentile of math CST, and a 10.5 percentage point gap at the $75^{\text {th }}$ percentile.
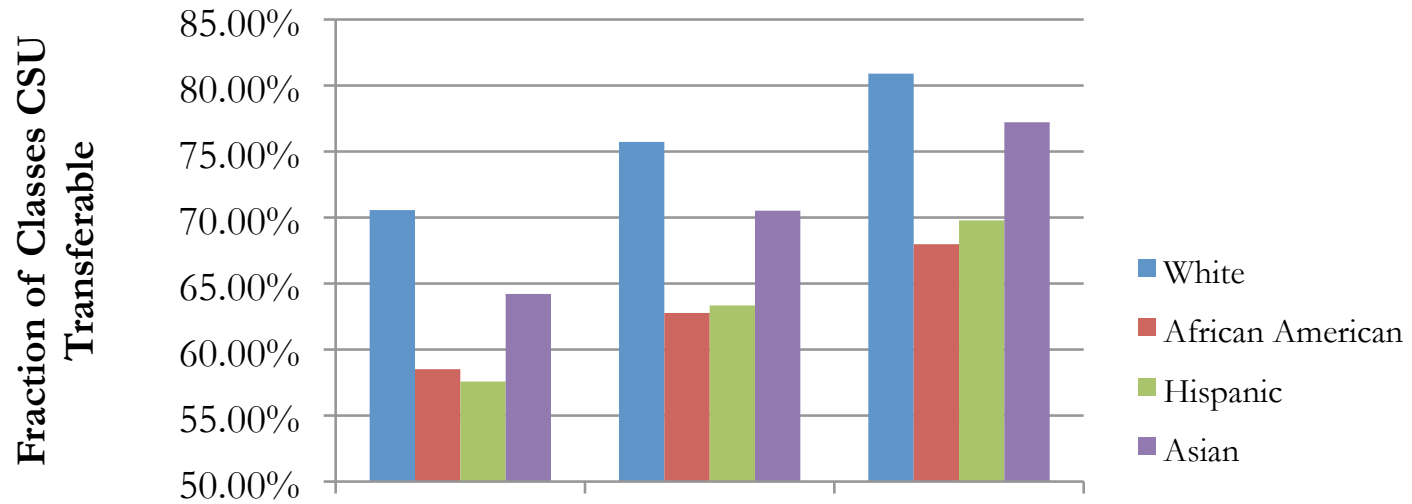

25th Percentile 50th Percentile 75th Percentile

English CST Percentile

Figure 1. Predicted fraction of classes that are CSU transferable by English CST percentile and race 


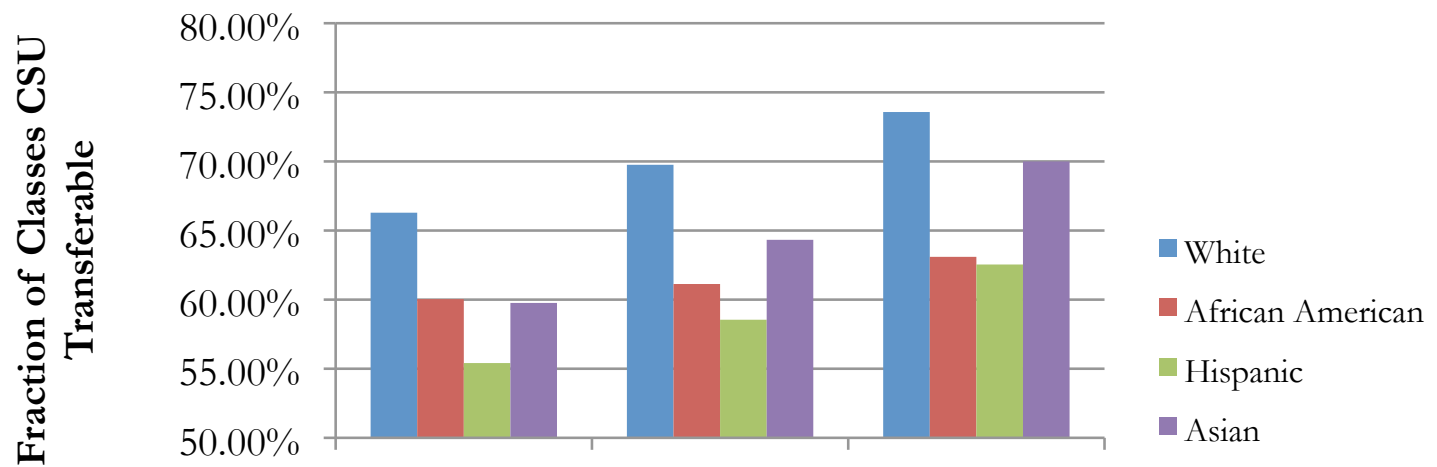

25th Percentile 50th Percentile 75th Percentile

Math CST Percentile

Figure 2. Predicted fraction of classes that are CSU transferable by math CST percentile and race

Turning to basic skills course-taking (Figure 3 and 4), we first note that students from all racial/ethnic groups, perhaps not surprisingly, have lower rates of first year basic skills course enrollment at higher high school achievement levels. However, these differences are not constant by racial/ethnic group. In English basic skills courses, we see the racial/ethnic gap in course-taking is significantly smaller at higher levels of English achievement. In math basic skills course, the gaps are much more stable across achievement levels, widening a bit between whites and Blacks, and narrowing a bit between whites and Latinos at higher rates of achievement.

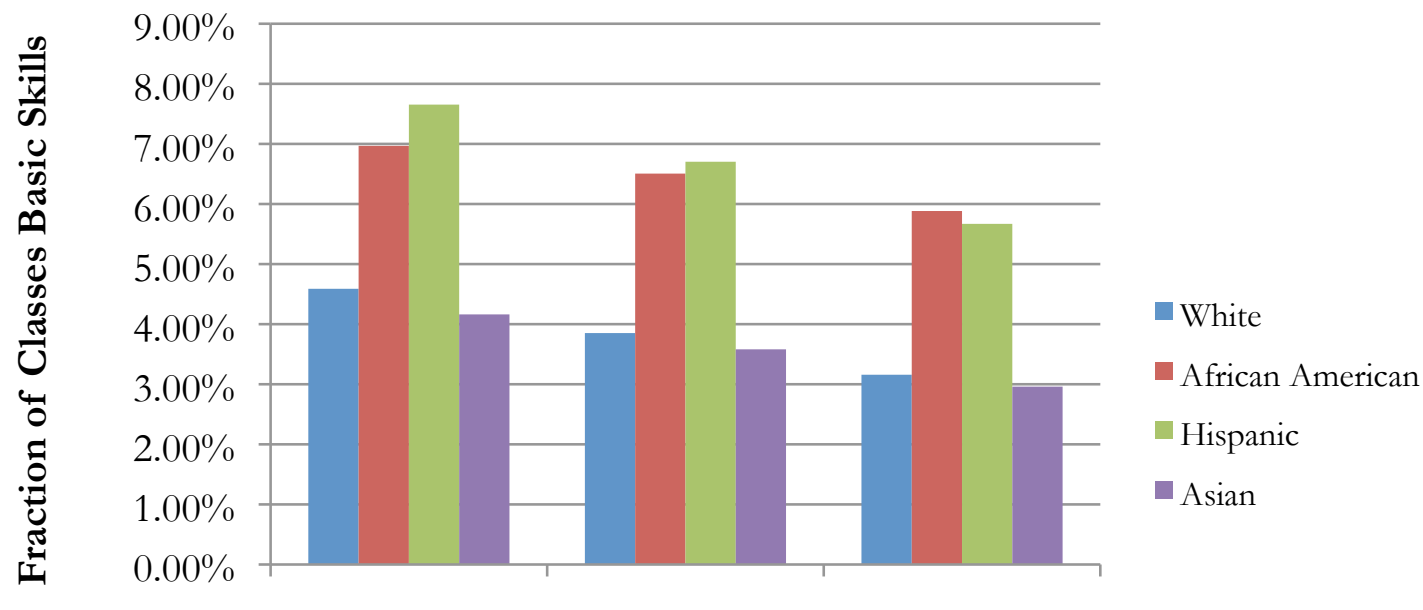

25th Percentile 50th Percentile 75th Percentile

\section{Math CST Percentile}

Figure 3. Predicted fraction of classes that are basic skills by English CST percentile and race 


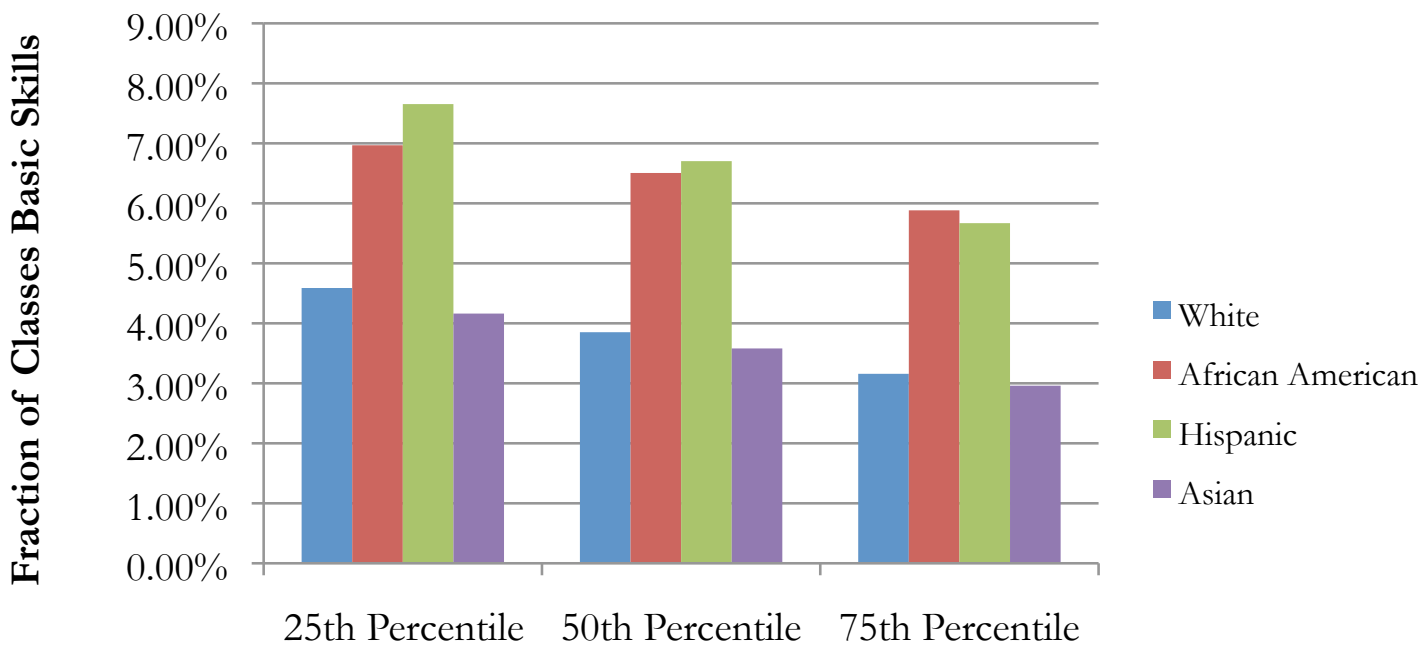

Math CST Percentile

Figure 4. Predicted fraction of classes that are basic skills by math CST percentile and race

Finally, turning to performance, Figures 5 and 6 display the fitted GPA for each respective racial/ethnic group as a function of prior high school achievement. Again, we note, first, regardless of race/ethnicity, all students have higher performance levels as freshmen in transferable courses, the higher their high school test scores. Second, we note that this relationship is different by race/ethnicity. Interestingly, the slope on English and math CST scores is steeper for whites and Asian students than for Latino and African American students in predicting GPA. Interestingly, we also find that the racial/ethnic gaps in performance are greatest at average values of high school achievement.

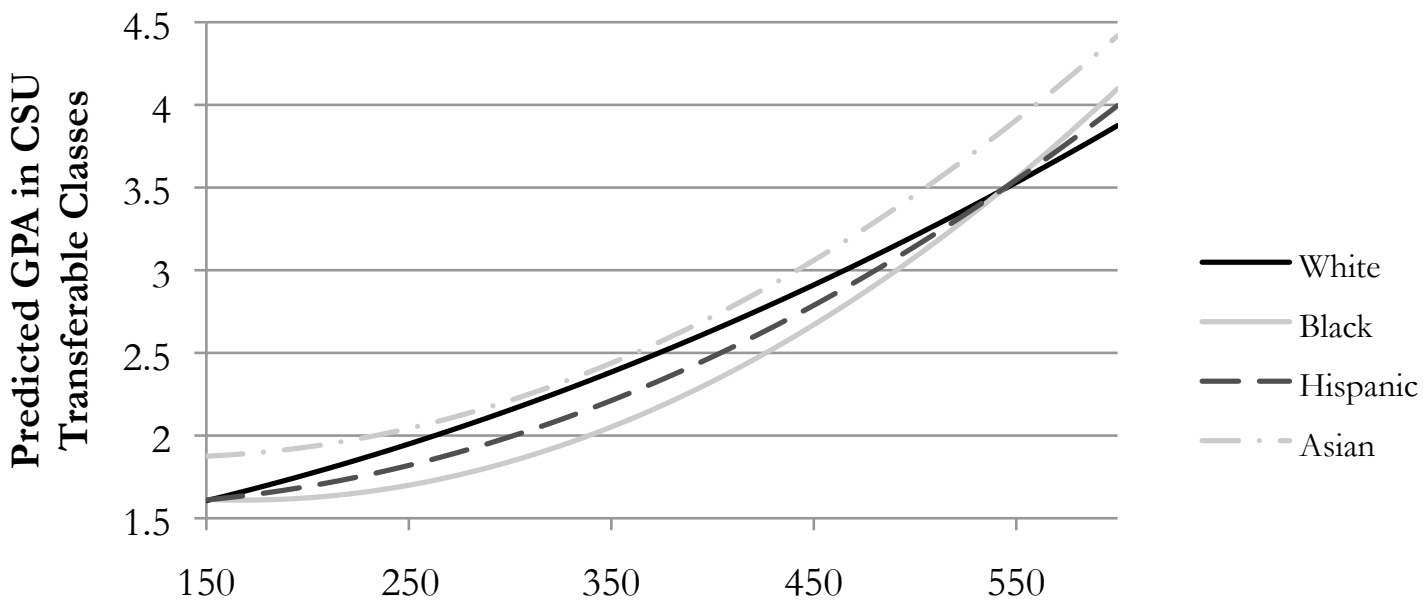

CST English Test Score

Figure 5. Predicted CSU transferable GPA based on English CST score 


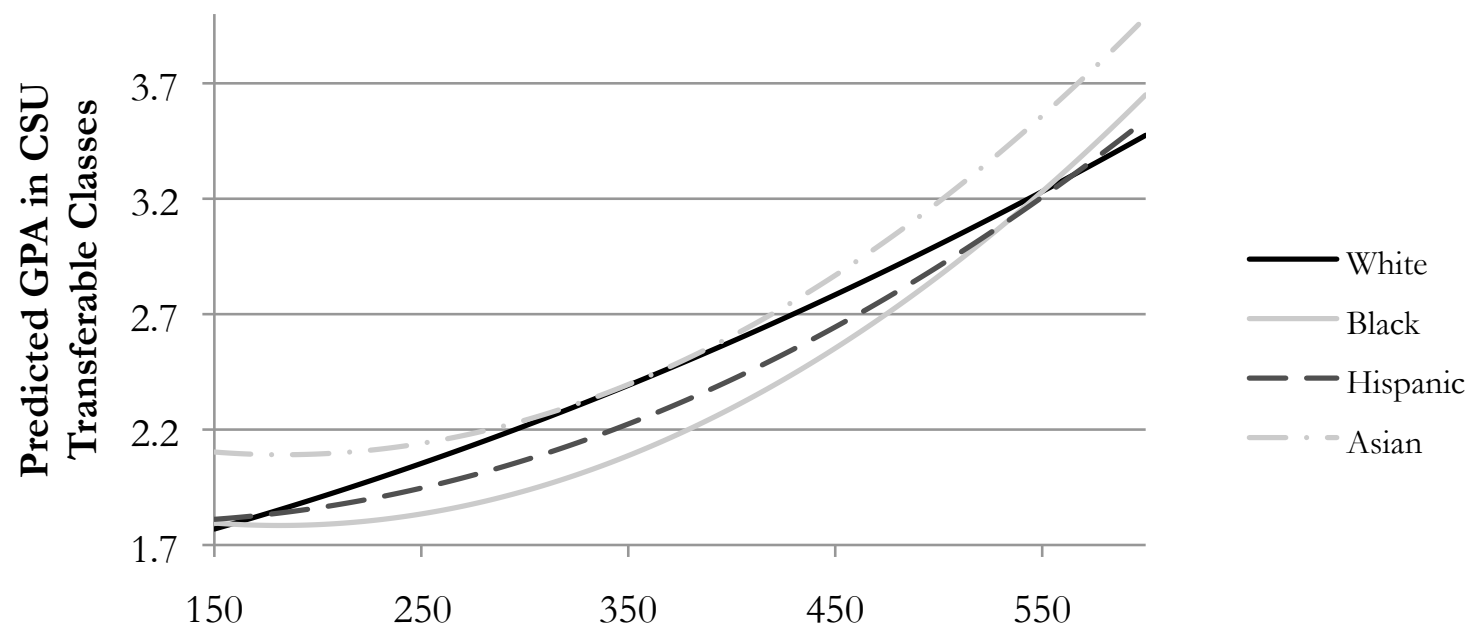

CST Math Test Score

Figure 6. Predicted CSU transferable GPA based on math CST score

\section{Limitations}

There are several important limitations to our analysis. First, it is important to note that this work is not causal. We can only conclude that high school academic performance is associated with these outcomes at community college, and not that it causes them. There are a host of unobserved differences that we cannot control for among test takers, which may also be associated with the outcomes we measure. As is evident in the R-square statistics we report in our models, much of the variation in these outcomes remains unexplained.

Second, given the varied ways in which California community colleges assess and assign students to courses, we are not able to determine the extent to which students' course placements are in fact appropriate. We only evaluate students in their first year at college, and some, for example, may require developmental courses, but are unable to enroll in them because they are impacted, and as a result are only enrolled in transfer-level courses. Some colleges may have rules similar to the California State University system that prevents students from taking any transfer-level courses until all developmental course needs are met, while others offer complete flexibility. To account for some of these institutional-level differences we include campus-level fixed effects. Moreover, because California community colleges do not request nor apply any information from students' high school academic background to course placements, we have no reason to suspect that the lack of standardization in course placements across the community college system would be systematically different by high school test scores.

\section{Discussion and Conclusion}

Community colleges are the primary point of access to higher education for many Americans. In California, two-thirds of all college students attend a community college. The role of community colleges as a vehicle in human capital production was the cornerstone of California's 1960 Master Plan for Higher Education, which stipulated that the California Community Colleges 
are to admit "any student capable of benefiting from instruction."7 The multiple missions and goals of community colleges have been well documented in the academic literature (Brint \& Karabel, 1983; Dougherty, 1994; Grubb, 199; Long \& Kurlaender, 2009; Melguizo, Kienzl, \& Alfonso, 2011; Rosenbaum, 2001). More recently, community colleges have also captured the attention of policymakers concerned with improving workforce shortages and the overall economic health of the nation. The Obama Administration identified community colleges as key drivers in the push to increase the stock of college graduates in the U.S. and to raise the skills of the American workforce. "It's time to reform our community colleges so that they provide Americans of all ages a chance to learn the skills and knowledge necessary to compete for the jobs of the future," remarked President Obama at the White House Summit on Community Colleges. ${ }^{8}$

The rising demands for skilled workers in California necessitate the need to strengthen the community colleges to accommodate much of this expansion (Public Policy Institute of California, 2010). Over the years, the California community colleges have grown and have been applauded for remaining affordable, open-access institutions. However, the state's community colleges are also continually criticized for producing weak outcomes, in particular low degree receipt and transfer rates to four-year institutions (Shulock \& Moore, 2007; Sengupta \& Jepsen, 2006). California's community colleges continue to address their multiple missions and the diverse goals of their students, often absent information about their students' educational backgrounds.

Our analysis offers several important findings of consequence for research, policy, and practice. First, we extend an important finding in the educational attainment literature about the influence of secondary school achievement on postsecondary outcomes for students attending community colleges. Specifically, we utilize a unique administrative dataset of the nation's largest community college system to understand the extent to which $\mathrm{K}-12$ standardized tests are useful for predicting postsecondary success. In many states, including California, data systems do not enable longitudinal assessments of students' educational pathways across the segments. However, it is clear that information about students' academic performance in high school may be useful to community colleges for course placement and for identifying students who may be in academic risk. Alas, community colleges rarely obtain such information about their students when they arrive.

Second, we find important differences in the fundamental relationship between prior achievement and postsecondary outcomes by race. There are persistent disparities in first-year course-taking and grades at community colleges by race/ethnicity; white and Asian students consistently have higher rates of transfer-level course taking, lower rates of basic skills course-taking, and higher grades than their Latino and African American counterparts at similar levels of prior achievement. These disparities, even controlling for high school test scores, suggest that there are clearly other factors (observed or unobserved) that lead to systematic differences in outcomes between students from different racial/ethnic groups. These may include, and are certainly not limited to, individual factors such as knowledge of college expectations, ability to navigate college

\footnotetext{
7 The California Master Plan for Higher Education articulated the distinct functions of each of the State's three public postsecondary segments. The University of California (UC) is designated to as the state's primary academic research institution and is reserved for the top one eighth of the State's graduating high school class. The California State University (CSU) is primarily to serve the top one-third of California's high school graduating class in undergraduate training, and graduate training through the master's degree, focusing primarily on professional training such as teacher education. Finally, the California Community Colleges are to provide academic and instruction for students through the first two years of undergraduate education (lower division), as well as provide vocational instruction, remedial instruction, English as a Second Language courses, adult noncredit instruction, community service courses, and workforce training services. 8 WhiteHouse.gov/CommunityCollege
} 
structures, familial supports, and quality of $\mathrm{K}-12$ schooling experiences, and the possibility of institutional level factors such as unequal expectations on the part of placement counselors or faculty. Importantly, we also find that gaps in these outcomes do not narrow consistently at higher rates of academic achievement, and in some cases actually widen.

Third, we find that the results, while robust to different model specifications, reveal that much of the variation in postsecondary course-taking is a between campus phenomena. This suggests that campuses of the community college system offer significantly different pathways of course-taking for students of similar prior high school achievement. California community colleges pride themselves on strong local governance of their campuses, and this is evident in placement policies and assessments. However, given that so much of the variation in course-taking is explained by campus affiliation it is imperative that researchers and community college leaders take a closer look at different campus policies and practices that may contribute to higher persistence rates and academic success for community college students. Recent initiatives such as Achieving the Dream ${ }^{9}$ and Completion by Design ${ }^{10}$ are efforts to improve the BA pathway for community college students, strengthening the articulation between community colleges and their neighboring four-year institutions. California has benefited from funding for such efforts, such as a Complete College America innovation grant (Complete College America, 2011). ${ }^{11}$

The rationale for improving the alignment of assessments across the secondary and postsecondary levels is that high school students (and institutions) can become better informed, and ultimately better prepared, for the requirements of college (Callan et al., 2006; Le, 2002). In an increasingly $\mathrm{K}-16$ policy environment, standards taught and tested in the $\mathrm{K}-12$ years should provide useful information to evaluate college readiness and success. A stronger connection between the public secondary and postsecondary systems should include the role of assessments. Efforts to extend California's Early Assessment Program (EAP) to the community colleges may formalize the use of secondary school tests for identifying college readiness at California's community colleges. ${ }^{12}$ Previous work suggests that the EAP may offer useful information about students' college readiness, above and beyond academic performance on the State's standardized test scores (Howell, Kurlaender, \& Grodsky, 2010). As such, community colleges stand to gain considerable utility (and perhaps efficiency) in implementing the EAP for purposes of remediation assessment and course placement.

Community college students face a number of structural, financial, and informational barriers including a lack of coherent coordination between $\mathrm{K}-12$ and postsecondary education systems and across state postsecondary systems. Our results highlight some of these barriers, and suggest that they may be experienced to a greater degree by students from particular racial/ethnic backgrounds. Others have argued that the educational system is fraught with market failures as a result of lack of information about the process for postsecondary entry, (e.g. financial aid procedures and admissions standards at four-year institutions), and other barriers that may limit the opportunity sets of students from disadvantaged backgrounds (Dougherty \& Kienzl, 2006).

Prior scholarship on the educational outcomes of community colleges has rarely focused on institutional factors that may facilitate or impede students' degree goals (Moore, Shulock, \& Jensen, 2009). Our results further suggest that institutional differences may play an important role in facilitating student success. Among its many features, the California Master Plan is widely recognized for transforming a "collection of uncoordinated and competing colleges and universities into a

\footnotetext{
${ }^{9}$ http://www.achievingthedream.org/

$10 \mathrm{http}: / /$ completionbydesign.org/

11 http://www.completecollege.org/

12 http://www.collegeeap.org/
} 
coherent system," and for providing broad access to higher education for citizens of the state of California. ${ }^{13}$ Fifty years later, it is clear that the coherent system envisioned by the architects of the Master Plan is plagued by weak articulation and rough transitions between high school and college and between two year and four-year colleges.

\section{References}

Achieve, Inc. (2004). The expectations gap: A 50-state review of high school graduation requirements. Washington, DC: Achieve, Inc.

Adelman, C. (2006). The toolbox revisited: Paths to degree completion from high school through college. Washington, DC: U.S. Department of Education.

Adelman, C. (1999). Answers in the tool box: Academic intensity, attendance patterns, and bachelor's degree attainment. Washington, DC: U.S. Department of Education.

Attewell, P. A., Lavin, D. E., Domina, T., \& Levey, T. (2006). New evidence on college remediation. The Journal of Higher Education, 77(5), 886-924.

Amrein, A. L. \& Berliner, D. C. (2002). High-stakes testing, uncertainty, and student learning. Education Policy Analysis Archives, 10(18).

Bailey, T. (2009). Challenge and opportunity: Rethinking the role and function of developmental education in community college. New Directions for Community Colleges, 145, 11-30.

Baum, S., Ma, J., \& Payea, K. (2010). Education pays: The benefits of higher education for individuals and society. New York, NY: The College Board.

Bettinger, Eric P. \& Bridget Terry Long. (2009). Addressing the needs of underprepared students in higher education: Does college remediation work? Journal of Human Resources, 44(3), 736-71.

Boatman, A \& Long, B.T. (2010). Does remediation work for all students? How the effects of postsecondary remedial and developmental courses vary by level of academic preparation. National Center for Postsecondary Research Working Paper.

Bozick, R. \& Lauff, E. (2007). Education longitudinal study of 2002 (ELS:2002): A first look at the initial postsecondary experiences of the sophomore class of 2002 (NCES 2008-308). Washington, DC: National Center for Education Statistics, Institute of Education Sciences, U.S. Department of Education. Washington, DC.

Brint, S. \& Karabel, J. (1989). The diverted dream: Community colleges and the promise of educational opportunity in America, 1900-1985. New York: Oxford University Press.

Calcagno, J. C. \& Long, B. T. (2008). The impact of postsecondary remediation using a regression discontinuity approach: Addressing endogenous sorting and noncompliance. (NBER Working Paper. No. 14194).

Retrieved from the National Bureau of Economic Research website: http://www.nber.org/papers/w14194

California Community Colleges Chancellor's Office. (2012). Management Information Systems Data Mart Available at: http://datamart.cccco.edu/Students/Enrollment_Status.aspx

Callan, P. M., Finney, J. E., Kirst, M. W., Usdan, M. D., \& Venezia, A. (2006). Claiming common ground: State policymaking for improving college readiness and success. San Jose, CA: National Center for Public Policy and Higher Education.

California Postsecondary Education Commission, California Community College Students' Degrees and Certificates Awarded and Successful Transfers, March 2007. Available at: http://www.cpec.ca.gov/completereports/2007reports/07- 06.pdf

${ }^{13}$ California Master Plan for Higher Education. Available at:

http://www.ucop.edu/acadinit/mastplan/MasterPlan1960.pdf 
Conley, D. T. (2005). College knowledge: What it really takes for students to succeed and what we can do to get them ready. San Francisco: Jossey-Bass.

Crouse, J. \& Trusheim, D. (1988). The case against the SAT. IL: University of Chicago Press.

Deil-Amen, R. \& Rosenbaum, J. E. (2002). The unintended consequences of stigma-free remediation. Sociology of Education, 75(3), 249-68.

Dougherty, K. J., \& Kienzl, G. S. (2006). It's not enough to get through the open door: Inequalities by social background in transfer from community colleges to four-year colleges. Teachers College Record, 108(3), 452-487.

Dougherty, K. (1994). The contradictory college: The conflicting origins, impacts, and futures of the community college. Albany, NY: State University of New York Press.

Dougherty, K. (1987). The effects of community colleges: Aid or hindrance to socioeconomic attainment? Sociology of Education, 60(2), 86-103.

Goldin, C. \& Katz, L. (2008). The race between education and technology. Cambridge, MA: Harvard University Press.

Grodsky, E., Warren, J. R., \& Felts, F. (2008). Testing and social stratification in American education. Annual Review of Sociology, 34, 385-404.

Grubb, W. N. (1991). The decline of community college transfer rates: Evidence from national longitudinal surveys. Journal of Higher Education, 62(2), 194-222.

Hoachlander, G., Sikora, A. C., \& Horn, L. J. (2003). Community college students: Goals, academic preparation and outcomes (NCES publication No. 2003-164). Washington, DC: National Center for Education Statistics.

Hoffman, N., Vargas, J. A., Venezia. A., \& Miller, S. M. (Eds.). (2007). Minding the gap: Why integrating high school with college makes sense and how to do it. Cambridge, MA: Harvard Education Press.

Howell, J., Kurlaender, M., \& Grodsky, E. (2010). Postsecondary preparation and remediation: Examining the effect of the Early Assessment Program at California State University. Journal of Policy Analysis and Management, 29(4), 726-748.

Hughes, K. L. \& Scott-Clayton, J. (2011). Assessing developmental assessment in community colleges. Assessment of Evidence Series. New York: Community College Research Center.

Kirst, M. (2000). Overcoming the high school senior slump: New education policies. Palo Alto, CA: Stanford University.

Kirst, M. \& Venezia, A. (Eds.). (2004). From high school to college: Improving opportunities for success in postsecondary education. San Francisco: Jossey-Bass.

Le, V. (2002). Alignment among secondary and post-secondary assessments in five case study states. CA: RAND.

Lemann, N. (1999). The big test: The secret history of the American meritocracy. NY: Farrar, Straus, and Giroux.

Lesik, S. (2007). Do developmental mathematics programs have a causal impact on student retention? An application of discrete-time survival and regression-discontinuity analysis. Research in Higher Education, 48(5), 583-608.

Long, B. T. \& Kurlaender, M. (2009). Do community colleges provide a viable pathway to a baccalaureate degree? Educational Evaluation and Policy Analysis, 31(1), 30-53.

Long, M.C., Iatarola, P., \& Conger, D. (2008). Explaining gaps in readiness for college-level math: The role of high school courses. Education Finance and Policy, 4(1), 1-33.

Martorell, P. \& McFarlin, I. (2011). Help or hindrance? The effects of college remediation on academic and labor market outcomes. Review of Economics and Statistics, 93(2), 436-54.

Melguizo, T., Kienzl, G. S., \& Alfonso, M. (2011). Comparing the educational attainment of community college transfer students and four-year college rising juniors using propensity score matching methods. The Journal of Higher Education, 82(3), 265-291. 
Moore, C., Shulock, N., \& Jensen, C. (2009). Crafting a student-centered transfer process in California: Lessons from other states. Sacramento, CA: Institute for Higher Education Leadership \& Policy. Available at: http://www.csus.edu/ihelp/PDFs/R Transfer Report 08-09.pdf

Perin, D. (2006). Can community colleges protect both access and standards? The problem of remediation. Teachers College Record, 108(3), 339-373.

Person, A. E., Rosenbaum, J. E., \& Deil-Amen, R. (2006). Student planning and information problems in different college structures. Teachers College Record, 108, 374-396.

Phipps, R. A. (1998). College remediation: What it is, what it costs, what's at stake. Washington, DC: Institute for Higher Education Policy.

Johnson, H. (2010). Educating California: Choice for the future. San Francisco, CA: Public Policy Institute of California.

Rosenbaum, J. E. (2001). Beyond college for all: Career paths for the forgotten half. New York: Russell Sage Foundation

Reynolds, J., Stewart, M., MacDonald, R., \& Sischo, L. (2006). Have adolescents become too ambitious? High school seniors' educational and occupational plans, 1976 to 2000. Social Problems, 53(2), 186-206.

Scott-Clayton, J. (2012). Do High-Stakes Placement Exams Predict College Success? (CCRC Working Paper No. 41). Retrieved from the Community College Research Center website: http://ccrc.tc.columbia.edu/Publication.asp?UID=1026

Scott-Clayton, J. \& Rodriguez, O. (2012). Development, discouragement, or diversion? New evidence on the effects of college remediation. (NBER Working Paper No. 18328). Retrieved from the National Bureau of Economic Research website: http://www.nber.org/papers/w18328

Sengupta, R. \& Jepsen, C. (2006). California's community college students. California Counts: Population Trends and Profiles, 8(2). Public Policy Institute of California.

Shulock, N. \& Moore, C. (2007). Rules of the game: How state policy creates barriers to degree completion and impedes student success in the California community colleges. Sacramento, CA: Institute for Higher Education and Leadership.

Snyder, T. D., Tan, A. G., \& Hoffman, C. M. (2004). Digest of education statistics 2003 (NCES Publication No. 2005-025). Washington, DC: National Center for Education Statistics.

Strong American Schools. (2008). Diploma to nowhere. Washington, DC: Strong American Schools. U.S. Department of Education. (2006). A test of leadership: Charting the future of U.S. higher education. Washington, DC: U.S. Department of Education.

Venezia, A., Kirst, M., \& Antonio, A. (2004). Betraying the college dream: How disconnected K-12 and postsecondary systems undermine student aspirations. San Francisco: Jossey-Bass.

Venezia, A., Callan, P. M., Finney, J. E., Kirst, M. W., \& Usdan, M. D. (2005). The governance divide: A report on a four-state study on improving college readiness and success. San Jose, CA: The National Center for Public Policy and Higher Education. 


\section{Appendix}

Table A1

Rates of Remedial Course-taking at Two-year and Four-year Institutions for the High School Class of 2004, by Race/Ethnicity

\begin{tabular}{lcccccc}
\hline & \multicolumn{3}{c}{ 4-Year Institutions } & \multicolumn{3}{c}{ 2-Year Institutions } \\
\hline & Reading & Writing & Math & Reading & Writing & Math \\
Total & 0.162 & 0.248 & 0.258 & 0.269 & 0.298 & 0.387 \\
By Race/Ethnicity: & & & & & & \\
White & 0.151 & 0.241 & 0.237 & 0.228 & 0.272 & 0.366 \\
African American/Black & 0.162 & 0.199 & 0.297 & 0.345 & 0.306 & 0.405 \\
Hispanic & 0.222 & 0.309 & 0.362 & 0.321 & 0.345 & 0.44 \\
Asian & 0.214 & 0.335 & 0.284 & 0.401 & 0.442 & 0.464 \\
\hline \hline
\end{tabular}

Source: U.S. Department of Education, National Center for Education Statistics, Education Longitudinal Study of 2002 (ELS:2002). Estimates in this table are based on spring 2004 high school seniors who had enrolled in postsecondary education by 2006. 
Table A2

Regression Results with Race Interactions - English

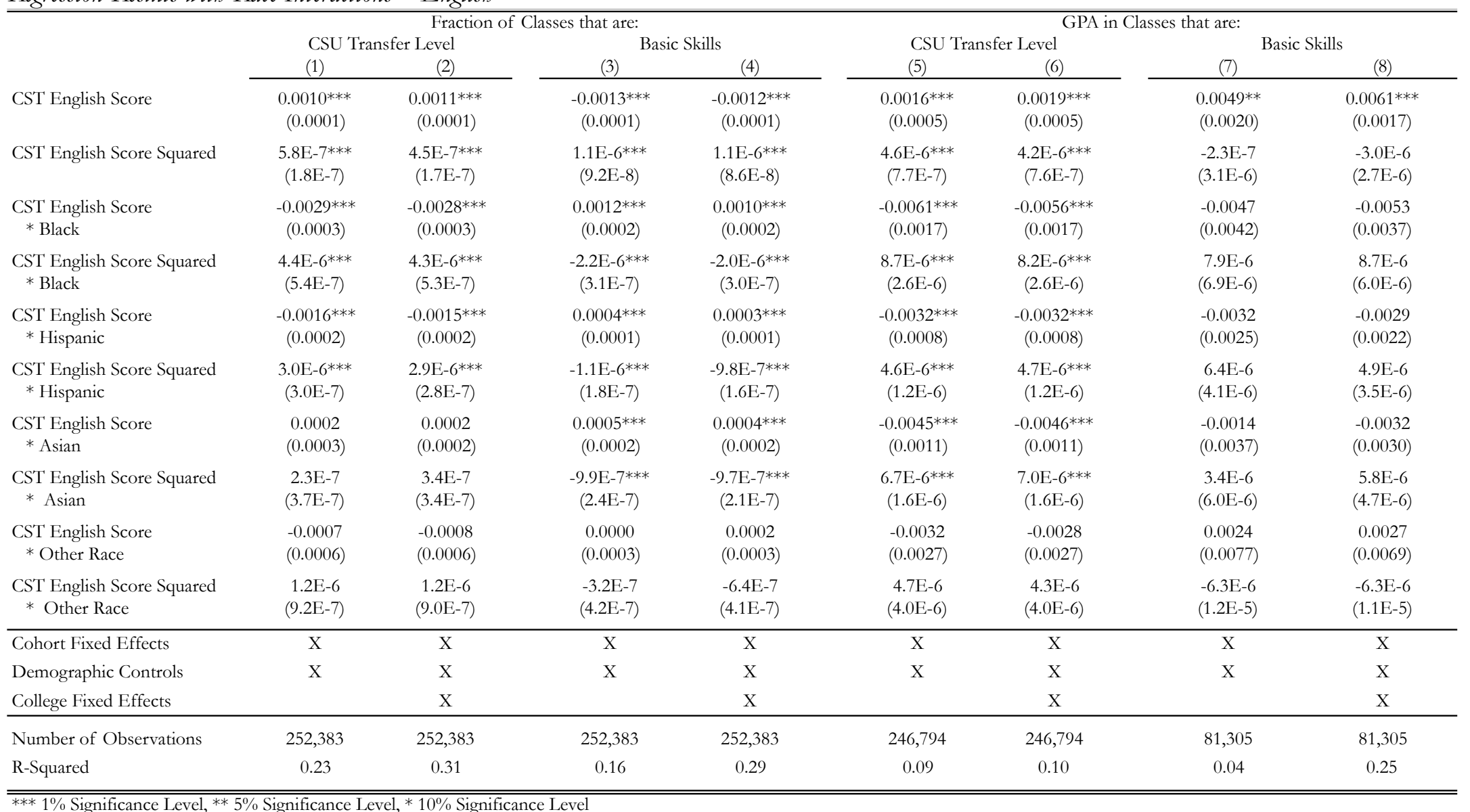

Notes: Demographic controls include indicator variables for race, gender, and parent college attendance. Cohorts are from the 2005-2006 school year to the 2009-2010 school year. Standard Errors are clustered at the high school level. GPA is the average Grade Point average in courses taken for a grade. Basic Skills definition is as defined by the California Community College Chancellor's office.

Source: Data are from the California Community College Chancellor's Office 
Table A3

Regression Results with Race Interactions - Math

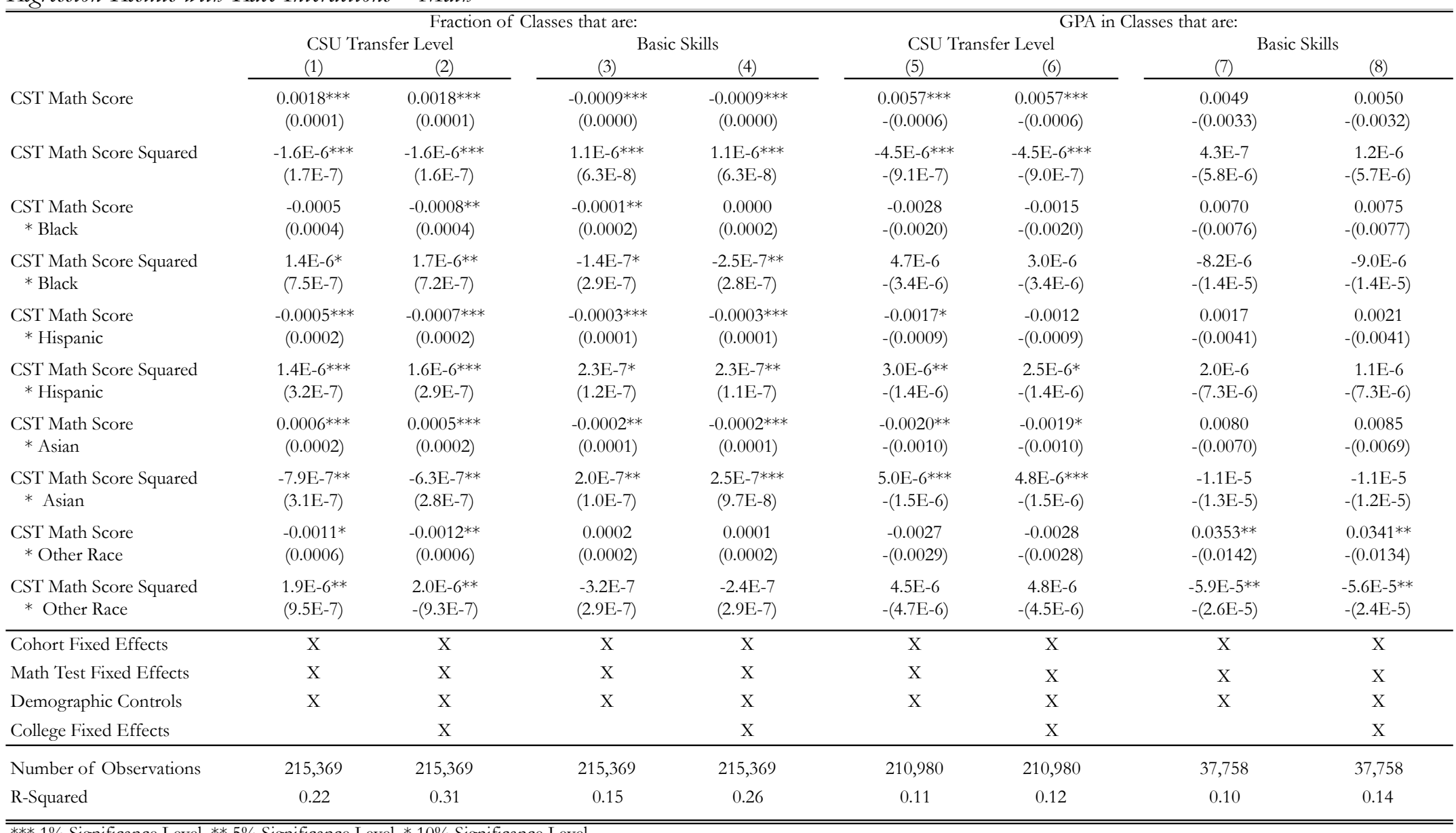

Notes: Demographic controls include indicator variables for race, gender, and parent college attendance. Cohorts are from the 2005-2006 school year to the 2009-2010 school year. Standard Errors are clustered at the high school level. GPA is the average Grade Point average in courses taken for a grade. Basic Skills definition is as defined by the California Community College Chancellor's office. Only those students who took the Algebra 1, Algebra2, Geometry, or Summative Math test are included in the analysis.

Source: Data are from the California Community College Chancellor's Office 


\section{About the Authors}

Michal Kurlaender

University of California, Davis, Department of Education

mkurlaender@ucdavis.edu

Michal Kurlaender is Associate Professor of Education at the University of California, Davis. Her work focuses on education policy and evaluation, particularly factors that influence inequality at various stages of the educational attainment process. Currently Dr. Kurlaender is conducting a statewide evaluation of a program intended to improve college readiness for California students.

Matthew F. Larsen

Tulane University, Department of Economics and The Murphy Institute mlarsen1@,tulane.edu

Matthew Larsen is a post-doctoral fellow with the Economics Department and the Murphy Institute at Tulane University. His dissertation (2012) examined various externalities of education policies. Currently, his research focuses on financial aid, school choice, and student mobility.

\section{Acknowledgements}

This research was supported in part by grants from the Institute of Education Sciences of the U.S. Department of Education and the Bill and Melinda Gates Foundation. We thank the California Department of Education and the California Community College Chancellor's Office for their assistance with data access. Opinions reflect those of the authors and do not necessarily reflect those of the granting agencies or the state agencies providing data.

\section{About the Guest Editors}

Dr. Jeanne M. Powers

Associate Professor

Mary Lou Fulton Teachers College

Arizona State University

jeanne.powers@asu.edu

Dr. Powers received her Ph.D. in Sociology from the University of California, San Diego. Her research focuses on school choice, accountability policies, school finance litigation, and school segregation. Her book, Charter Schools: Reform Imagery, Reform Reality, was published in June 2009 by Palgrave Macmillan. One of Dr. Powers' ongoing projects is a historical analysis of Mexican American school segregation cases in the Southwest. For an example of this line of research, see, "Between Mendez and Brown: Gonzales v. Sheely (1951) and the Legal Campaign Against Segregation" (with Lirio Patton), an analysis of the legal arguments in Mexican American school segregation cases, which was published in March 2008 in Law and Social Inquiry. In another line of research she is examining how social science research shapes judicial decisionmaking in school finance cases. Dr. Powers' research has also been 
published in American Educational Research Journal, Educational Policy, and Equity and Excellence in Education. Dr. Powers is currently an Associate Editor of Education Policy Analysis Archives.

Amelia M. Topper

Doctoral Student, Education Policy and Evaluation

Mary Lou Fulton Teachers College

Arizona State University

amy.topper@asu.edu

Ms. Topper has worked in the education sector for over 15 years as both an educator and researcher, and is currently pursuing a Ph.D. in Education Policy and Evaluation at Arizona State University. Ms. Topper has experience working on studies for the U.S. Department of Education, the Lumina Foundation, the Bill \& Melinda Gates Foundation, the Pell Institute, state agencies, and local school districts. She works with Achieving the Dream, a national community college reform movement, and has authored and co-authored numerous policy briefs on the initiative-wide database. Topics of research include postsecondary student access, persistence and retention; financial aid policies; community colleges; and, K-12 student migration and charter school enrollment. Ms. Topper's research has been published in Review of Education Research, Journal of School Choice, and On the Horizon, and she is currently a Managing Editor of Education Policy Analysis Archives. She holds a Master's in Leadership in Teaching from the College of Notre Dame of Maryland, and a Bachelor's in the Philosophy and Classical Languages from St. John's College, Annapolis, Maryland.

\title{
SPECIAL ISSUE \\ The American Community College in the $21^{\text {st }}$ Century education policy analysis archives
}

\author{
Volume 21 Number $16 \quad$ February $27^{\text {th }}, 2013 \quad$ ISSN 1068-2341
}

\begin{abstract}
@)
SOMEREIGHISRESERVED Readers are free to copy, display, and distribute this article, as long as the work is attributed to the author(s) and Education Policy Analysis Archives, it is distributed for non-commercial purposes only, and no alteration or transformation is made in the work. More details of this Creative Commons license are available at http://creativecommons.org/licenses/by-nc-sa/3.0/. All other uses must be approved by the author(s) or EPAA. EPAA is published by the Mary Lou Fulton Institute and Graduate School of Education at Arizona State University Articles are indexed in CIRC (Clasificación Integrada de Revistas Científicas, Spain), DIALNET (Spain), Directory of Open Access Journals, EBSCO Education Research Complete, ERIC, Education Full Text (H.W. Wilson), QUALIS A2 (Brazil), SCImago Journal Rank; SCOPUS, SOCOLAR (China).
\end{abstract}

Please contribute commentaries at http://epaa.info/wordpress/ and send errata notes to Gustavo E. Fischman fischman@asu.edu 
Join EPAA's Facebook community at https://www.facebook.com/EPAAAAPE,

Twitter feed@epaa_aape, and Academia.edu page at:

http://asu.academia.edu/EPAAAAPE 


\section{education policy analysis archives editorial board}

Editor Gustavo E. Fischman (Arizona State University)

Associate Editors: David R. Garcia (Arizona State University), Stephen Lawton (Arizona State University)

Rick Mintrop, (University of California, Berkeley) Jeanne M. Powers (Arizona State University)

Jessica Allen University of Colorado, Boulder

Gary Anderson New York University

Michael W. Apple University of Wisconsin, Madison

Angela Arzubiaga Arizona State University

David C. Berliner Arizona State University

Robert Bickel Marshall University

Henry Braun Boston College

Eric Camburn University of Wisconsin, Madison

Wendy C. Chi* University of Colorado, Boulder

Casey Cobb University of Connecticut

Arnold Danzig Arizona State University

Antonia Darder University of Illinois, UrbanaChampaign

Linda Darling-Hammond Stanford University

Chad d'Entremont Strategies for Children

John Diamond Harvard University

Tara Donahue Learning Point Associates

Sherman Dorn University of South Florida

Christopher Joseph Frey Bowling Green State University

Melissa Lynn Freeman* Adams State College

Amy Garrett Dikkers University of Minnesota

Gene V Glass Arizona State University

Ronald Glass University of California, Santa Cruz

Harvey Goldstein Bristol University

Jacob P. K. Gross Indiana University

Eric M. Haas WestEd

Kimberly Joy Howard* University of Southern California

Aimee Howley Ohio University

Craig Howley Ohio University

Steve Klees University of Maryland

Jaekyung Lee SUNY Buffalo
Christopher Lubienski University of Illinois, UrbanaChampaign

Sarah Lubienski University of Illinois, Urbana-

Champaign

Samuel R. Lucas University of California, Berkeley

Maria Martinez-Coslo University of Texas, Arlington

William Mathis University of Colorado, Boulder

Tristan McCowan Institute of Education, London

Heinrich Mintrop University of California, Berkeley

Michele S. Moses University of Colorado, Boulder

Julianne Moss University of Melbourne

Sharon Nichols University of Texas, San Antonio

Noga O'Connor University of Iowa

João Paraskveva University of Massachusetts, Dartmouth

Laurence Parker University of Illinois, UrbanaChampaign

Susan L. Robertson Bristol University

John Rogers University of California, Los Angeles

A. G. Rud Purdue University

Felicia C. Sanders The Pennsylvania State University

Janelle Scott University of California, Berkeley

Kimberly Scott Arizona State University

Dorothy Shipps Baruch College/CUNY

Maria Teresa Tatto Michigan State University

Larisa Warhol University of Connecticut

Cally Waite Social Science Research Council

John Weathers University of Colorado, Colorado Springs

Kevin Welner University of Colorado, Boulder

Ed Wiley University of Colorado, Boulder

Terrence G. Wiley Arizona State University

John Willinsky Stanford University

Kyo Yamashiro University of California, Los Angeles

* Members of the New Scholars Board 


\section{archivos analíticos de políticas educativas consejo editorial}

Editor: Gustavo E. Fischman (Arizona State University)

Editores. Asociados Alejandro Canales (UNAM) y Jesús Romero Morante (Universidad de Cantabria)

Armando Alcántara Santuario Instituto de Investigaciones sobre la Universidad y la Educación, UNAM México

Claudio Almonacid Universidad Metropolitana de Ciencias de la Educación, Chile

Pilar Arnaiz Sánchez Universidad de Murcia, España

Xavier Besalú Costa Universitat de Girona, España Jose Joaquin Brunner Universidad Diego Portales, Chile

Damián Canales Sánchez Instituto Nacional para la Evaluación de la Educación, México

María Caridad García Universidad Católica del Norte, Chile

Raimundo Cuesta Fernández IES Fray Luis de León, España

Marco Antonio Delgado Fuentes Universidad Iberoamericana, México

Inés Dussel FLACSO, Argentina

Rafael Feito Alonso Universidad Complutense de Madrid, España

Pedro Flores Crespo Universidad Iberoamericana, México

Verónica García Martínez Universidad Juárez Autónoma de Tabasco, México

Francisco F. García Pérez Universidad de Sevilla, España

Edna Luna Serrano Universidad Autónoma de Baja California, México

Alma Maldonado Departamento de Investigaciones Educativas, Centro de Investigación y de Estudios Avanzados, México

Alejandro Márquez Jiménez Instituto de Investigaciones sobre la Universidad y la Educación, UNAM México

José Felipe Martínez Fernández University of California Los Angeles, USA
Fanni Muñoz Pontificia Universidad Católica de Perú

Imanol Ordorika Instituto de Investigaciones Economicas - UNAM, México

Maria Cristina Parra Sandoval Universidad de Zulia, Venezuela

Miguel A. Pereyra Universidad de Granada, España

Monica Pini Universidad Nacional de San Martín, Argentina

Paula Razquin UNESCO, Francia

Ignacio Rivas Flores Universidad de Málaga, España

Daniel Schugurensky Universidad de Toronto-Ontario Institute of Studies in Education, Canadá

Orlando Pulido Chaves Universidad Pedagógica Nacional, Colombia

José Gregorio Rodríguez Universidad Nacional de Colombia

Miriam Rodríguez Vargas Universidad Autónoma de Tamaulipas, México

Mario Rueda Beltrán Instituto de Investigaciones sobre la Universidad y la Educación, UNAM México

José Luis San Fabián Maroto Universidad de Oviedo, España

Yengny Marisol Silva Laya Universidad Iberoamericana, México

Aida Terrón Bañuelos Universidad de Oviedo, España

Jurjo Torres Santomé Universidad de la Coruña, España

Antoni Verger Planells University of Amsterdam, Holanda

Mario Yapu Universidad Para la Investigación Estratégica, Bolivia 


\section{arquivos analíticos de políticas educativas conselho editorial}

Editor: Gustavo E. Fischman (Arizona State University) Editores Associados: Rosa Maria Bueno Fisher e Luis A. Gandin

(Universidade Federal do Rio Grande do Sul)

Dalila Andrade de Oliveira Universidade Federal de Minas Gerais, Brasil

Paulo Carrano Universidade Federal Fluminense, Brasil

Alicia Maria Catalano de Bonamino Pontificia Universidade Católica-Rio, Brasil

Fabiana de Amorim Marcello Universidade Luterana do Brasil, Canoas, Brasil

Alexandre Fernandez Vaz Universidade Federal de Santa Catarina, Brasil

Gaudêncio Frigotto Universidade do Estado do Rio de Janeiro, Brasil

Alfredo M Gomes Universidade Federal de Pernambuco, Brasil

Petronilha Beatriz Gonçalves e Silva Universidade Federal de São Carlos, Brasil

Nadja Herman Pontificia Universidade Católica -Rio Grande do Sul, Brasil

José Machado Pais Instituto de Ciências Sociais da Universidade de Lisboa, Portugal

Wenceslao Machado de Oliveira Jr. Universidade Estadual de Campinas, Brasil
Jefferson Mainardes Universidade Estadual de Ponta Grossa, Brasil

Luciano Mendes de Faria Filho Universidade Federal de Minas Gerais, Brasil

Lia Raquel Moreira Oliveira Universidade do Minho, Portugal

Belmira Oliveira Bueno Universidade de São Paulo, Brasil

António Teodoro Universidade Lusófona, Portugal

Pia L. Wong California State University Sacramento, U.S.A

Sandra Regina Sales Universidade Federal Rural do Rio de Janeiro, Brasil

Elba Siqueira Sá Barreto Fundação Carlos Chagas, Brasil

Manuela Terrasêca Universidade do Porto, Portugal

Robert Verhine Universidade Federal da Bahia, Brasil

Antônio A. S. Zuin Universidade Federal de São Carlos, Brasil 